\title{
Compressive Strength and Ultrasonic Pulse Velocity of Concrete with Metakaolin
}

\author{
Mayuri A. Chandak ${ }^{1, *}$, P.Y. Pawade ${ }^{2}$ \\ ${ }^{1}$ Research Scholar, Department of Civil Engineering, G H Raisoni College of Engineering Nagpur, India \\ ${ }^{2}$ Professor, Department of Civil Engineering, G H Raisoni College of Engineering Nagpur, India
}

Received September 15, 2020; Revised November 3, 2020; Accepted November 19, 2020

\section{Cite This Paper in the following Citation Styles}

(a): [1] Mayuri A. Chandak, P.Y. Pawade, "Compressive Strength and Ultrasonic Pulse Velocity of Concrete with Metakaolin," Civil Engineering and Architecture, Vol. 8, No. 6, pp. 1277 - 1282, 2020. DOI: 10.13189/cea.2020.080611.

(b): Mayuri A. Chandak, P.Y. Pawade (2020). Compressive Strength and Ultrasonic Pulse Velocity of Concrete with Metakaolin. Civil Engineering and Architecture, 8(6), 1277 - 1282. DOI: 10.13189/cea.2020.080611.

Copyright $\bigcirc 2020$ by authors, all rights reserved. Authors agree that this article remains permanently open access under the terms of the Creative Commons Attribution License 4.0 International License

\begin{abstract}
The intention of the present study is to assess the possibility of using Metakaolin as a partial replacement of Portland Pozzolana Cement (PPC) in the concrete to improve its workability and compressive strength. It also explores the study on the connection between ultrasonic pulse velocity (UPV) on different replacement percentage of mineral metakaolin and compressive strength by using a compression testing machine for M40 grade of concrete. Concrete specimens were cast of size $150 \mathrm{mmx} 150 \mathrm{~mm}$ $\mathrm{x} 150 \mathrm{~mm}$ by partial replacing PPC with metakaolin in the range of $4 \%$ to $28 \%$ by the weight of cement. For better consistency and workability the Visco-Flux superplasticizer was used. Usual procedure of water curing of specimens was done for 7, 28, and 90 days to determine the effect of curing time on strength. All 8 different mix specimens were tested for compressive strength and ultrasonic pulse velocity. It was observed that up to $24 \%$ metakaolin replacement the strength was increased but after that, the strength gets reduced as compared to the normal concrete and the optimum value of compressive strength was obtained at $16 \%$ metakaolin replacement. The increase in the UPV of test samples indicated the formation of the homogeneous structure due to the addition of metakaolin. So the use of metakaolin as a partial replacement of PPC in concrete is a good choice to reduce the cost of production and increase the strength of concrete. A mathematical model is generated by regression analysis in the form of an equation to correlate the compressive strength and ultrasonic pulse velocity.
\end{abstract}

Keywords MK (Metakaolin), Compressive Strength, Ultrasonic Pulse Velocity, Concrete

\section{Introduction}

Utilisation of Metakaolin as a pozzolanic binder in concrete blend is widely increased. Metakaolin is very different from other pozzolanic material because it is not the by-product as manufactured underneath carefully controlled environments [1]. It is made by calcinations of kaolin, one of the extensively available natural mineral. Fine and white color kaolin clay has conventionally been applied as a coating for paper and in the porcelain production. Usually metakaolin mineral is oxides of Aluminum and Silicon with small amounts of oxides of Calcium, Iron, Magnesium, Titanium, etc. MK has a white shade, which makes it appealing to architectural programs together with color matching [2]. Metakaolin due to higher degree of pozzolanic reactive improves mechanical properties of concrete reducing the cement consumption. Previous studies discovered an enormous interest in metakaolin because it has both micro filler in addition to pozzolanic properties [2-4]. Also it improves strength of concrete particularly in early stages of hydration $[5,6]$. Metakaolin has been successfully used for formation of high strength self-compacting concrete (HSSCC) and proved with the help of mathematical modeling [7]. Due to fineness of metakaolin dose of super plasticizer required is more in MK containing concretes [8]. Such concretes help in protecting the environment by reducing carbon dioxide $\left(\mathrm{CO}_{2}\right)$ and other greenhouse gas emissions related with cement production. 
These days the non destructive tests (NDT) like Ultrasonic pulse velocity test methods are used for examination of concrete quality. The basis of this method is the measurement of velocity propagation, which is closely related to mechanical properties and more directly relates to elastic modulus. The UPV portable device consists of a source/detector unit and a surface sensor, with an operating frequency range of 25 to $60 \mathrm{kHz}$ [9]. In all non-destructive testing methods, concrete is assumed to be a homogeneous material. This test is used to determine whether there is any damage/rupture, material discontinuity and intensity within a given exposure time. The measurement value is obtained by measuring the propagation time of an ultrasonic pulse between transducers on opposite ends of a given material. Knowing the span and propagation time between the transducers, the pulse velocity can be quickly found by dividing the length or span by the propagation time (Eq. (1)). High strength indicates higher density, integrity and quality of the material [10]

$$
\mathrm{V}(\mathrm{x}, \mathrm{t})=\mathrm{x} / \mathrm{t}
$$

Where, $V$ is the UPV value, $x$ is the length of concrete specimen and $t$ is the travel time. Many previous studies reported correlation between UPV and the compressive strength for a particular proportion concrete mix [1-5, 11-15] still, a relationship with a wide variation will be obtained if the required data of UPV and the compressive strength of different proportion concrete mixture are arrange and analyzed [11-15].

In this work, harden properties of compressive strength test and ultrasonic pulse velocity test were conducted on all the mixes; regression analysis is carried on the values obtained from the result of compressive strength test and ultrasonic pulse velocity test to check their interrelationship among them.

\section{Materials Used}

\subsection{Cement}

PPC confirming by (IS 1489:1991). Initial and final setting time is 136 minutes and 210 minutes respectively, soundness $0.5 \mathrm{~mm}$ and 28 days compressive strength is $55.60 \mathrm{~N} / \mathrm{mm}^{2}$. Chemical Properties of PPC are as given in Table 1.

Table 1. Chemical properties of cement

\begin{tabular}{|c|c|c|c|}
\hline $\begin{array}{c}\text { Sr. } \\
\text { No. }\end{array}$ & Contents & $\begin{array}{c}\text { Requirements as per IS } \\
\text { 1489( Part I): } 1991\end{array}$ & Results \\
\hline 1 & \% Magnesia & Not more than $6.0 \%$ & 1.1 \\
\hline 2 & $\begin{array}{c}\text { \% Insoluble } \\
\text { Residue }\end{array}$ & $\begin{array}{c}{[\mathrm{X}+4.0(100-\mathrm{X}) / 100] \mathrm{Max}} \\
(\mathrm{X} \text { is \% Pozzolana in PPC })\end{array}$ & 27.0 \\
\hline 3 & $\begin{array}{c}\text { \% Sulphur } \\
\text { Calculated As } \\
\text { SO3 }\end{array}$ & Not more than 3.0\% & 2.3 \\
\hline 4 & $\begin{array}{c}\text { \% Loss On } \\
\text { Ignition }\end{array}$ & Not more than $5.0 \%$ & 2.0 \\
\hline 5 & \% Chloride & - & 0.022 \\
\hline
\end{tabular}

\subsection{Metakaolin}

Metakaolin, quality enhancing pozzolana in amorphous powder form was marketed by the 20 Micron Ltd. at Vadodara, Gujarat with physical and chemical properties given in Table 2.

Table 2. Chemical and Physical properties of Metakaolin

\begin{tabular}{|c|c|c|}
\hline \multirow{4}{*}{ Properties } & Contents & $\begin{array}{c}\text { Results } \\
\text { (\% by mass) }\end{array}$ \\
\hline \multirow{4}{*}{ Chemical properties } & $\mathrm{SiO}_{2}$ & 53 \\
\cline { 2 - 3 } & $\mathrm{Al}_{2} \mathrm{O}_{3}$ & 43 \\
\cline { 2 - 3 } & $\mathrm{Fe}_{2} \mathrm{O}_{3}$ & 1.2 \\
\cline { 2 - 3 } & $\mathrm{CaO}$ & 0.5 \\
\cline { 2 - 3 } & $\mathrm{Na}_{2} \mathrm{O}$ & 0.12 \\
\cline { 2 - 3 } & $\mathrm{MgO}$ & 0.4 \\
\cline { 2 - 3 } & $\mathrm{K}_{2} \mathrm{O}$ & 0.53 \\
\cline { 2 - 3 } & $\mathrm{L.O.I.}$ & 0.4 \\
\cline { 2 - 3 } & $\mathrm{TiO}_{2}$ & 2.27 \\
\hline \multirow{7}{*}{ Physical properties } & Surface area (m $/$ kg) & 16800 \\
\cline { 2 - 3 } & Specific gravity & 2.6 \\
\hline
\end{tabular}

\subsection{Fine and Coarse Aggregate}

The fine aggregate used in the experimentation is locally available river sand complying with zone- II of IS 383(2016). The crushed stone were obtained from the local quarry was used as coarse aggregate. The coarse aggregates used in the experimentation were of $20 \mathrm{~mm}$ and $10 \mathrm{~mm}$ and tested as per IS: 2386-1963 (I, II and III) specifications.

\subsection{Superplasticizer}

To give the additional desired properties, a superplasticizer Visco Flux-2230+ was used for casting specimens of all the mixes. It conforms to IS: 9103-1999 and has a specific gravity of 1.1 .

\subsection{Water}

In experimentation fresh portable tap water which is free from acid concentration and organic substance is used for concrete mixing and for curing.

\section{Concrete Mix Proportion and Casting of Specimen}

The design mix proportion for M40 grade concrete as per standard was given in IS 10262:2009 and IS 456: 2000 was $(1: 1.69: 3.1)$ of binder $400 \mathrm{~kg} / \mathrm{m}^{3}$. The mix with water cement ratio 0.38 and the proportion of coarse aggregate (20mm): $(10 \mathrm{~mm})$ was $60: 40$. The different proportion of concrete mix components was used to improve workability 
of ppc with metakaolin concrete with proper dose of super plasticizer. All eight concrete mixes were used to cast 9 specimens per test series. The mixes were prepared by varying percentage of metakaolin from 0 to 28 with the interval of $4 \%$. The standard $150 \mathrm{~mm}$ cubes were casted for compressive strength test. For the mixing of concrete the electrical laboratory concrete mixer were used. Initially for first two minutes dry mixing was done and latter for one minute wet mixing of concrete. After casting molds were allowed to dry for 24 hours at room temperature. The specimen were demolded and kept in water tank for curing for 7, 28 and 90 days age. Table 3 reports the concrete mix proportions.

\section{Experimental Investigations}

\subsection{Compressive Strength}

The compression Test is done on cube of size 150x150x150 mm as per IS 516:1959 by compressive strength machine of capacity of $2000 \mathrm{KN}$. At all ages of curing compressive strength was performed.

\subsubsection{Effect of Metakaolin on Cube Compressive Strength and UPV Values}

The effect of addition of metakaolin as a replacement material to cement in concrete in various percentages, the compressive strength is increased significantly. The metakaolin is added in $4 \%, 8 \%, 12 \%, 16 \%, 20 \%, 24 \%$ and $28 \%$ by weight of cementitious material. The test is performed after completion of 7, 28 and 90 days of curing. The maximum compressive strength is found at $16 \%$ replacement of cement by metakaolin. It shows increment up to $10 \%$ over control concrete with a standard deviation of $4.15 \%$. The variation of change in compressive strength in percentage is shown in Figure 1.

Table 3. Concrete Mix proportion

\begin{tabular}{|c|c|c|c|c|c|c|c|c|c|c|}
\hline \multirow[b]{2}{*}{$\begin{array}{l}\text { Sr. } \\
\text { No. }\end{array}$} & \multirow[b]{2}{*}{$\begin{array}{l}\text { Concrete } \\
\text { mix }\end{array}$} & \multirow[b]{2}{*}{ PPC:MK } & \multirow[b]{2}{*}{ Metakaolin \% } & \multirow{2}{*}{$\begin{array}{c}\text { Total } \\
\text { binder } \\
\left(\mathrm{kg} / \mathrm{m}^{3}\right)\end{array}$} & \multirow{2}{*}{$\begin{array}{l}\mathrm{PPC} \\
(\mathrm{kg} / \\
\left.\mathrm{m}^{3}\right)\end{array}$} & \multirow[b]{2}{*}{$\begin{array}{l}\text { Metakaolin } \\
\left(\mathrm{kg} / \mathrm{m}^{3}\right)\end{array}$} & \multicolumn{2}{|c|}{ Aggregate } & \multirow[b]{2}{*}{$\mathrm{W} / \mathrm{C}$} & \multirow[b]{2}{*}{ SP \% } \\
\hline & & & & & & & $\begin{array}{l}\text { Fine } \\
(\mathrm{kg} / \\
\left.\mathrm{m}^{3}\right)\end{array}$ & $\begin{array}{l}\text { Coarse } \\
\left(\mathrm{kg} / \mathrm{m}^{3}\right)\end{array}$ & & \\
\hline 1 & S1 & $1.00: 0.00$ & 0 & 400 & 400 & 0 & 679 & 1258 & 0.38 & 0.55 \\
\hline 2 & S2 & $0.96: 0.04$ & 4 & 400 & 384 & 16 & 679 & 1258 & 0.38 & 0.55 \\
\hline 3 & S3 & 0.92:0.08 & 8 & 400 & 368 & 32 & 679 & 1258 & 0.38 & 0.6 \\
\hline 4 & S4 & 0.88:0.12 & 12 & 400 & 352 & 48 & 679 & 1258 & 0.38 & 0.65 \\
\hline 5 & S5 & $0.84: 0.16$ & 16 & 400 & 336 & 64 & 679 & 1258 & 0.38 & 0.7 \\
\hline 6 & S6 & $0.80: 0.20$ & 20 & 400 & 320 & 80 & 679 & 1258 & 0.38 & 0.75 \\
\hline 7 & S7 & $0.76: 0.24$ & 24 & 400 & 304 & 96 & 679 & 1258 & 0.38 & 0.8 \\
\hline 8 & S8 & $0.72: 0.28$ & 28 & 400 & 288 & 112 & 679 & 1258 & 0.38 & 0.85 \\
\hline
\end{tabular}
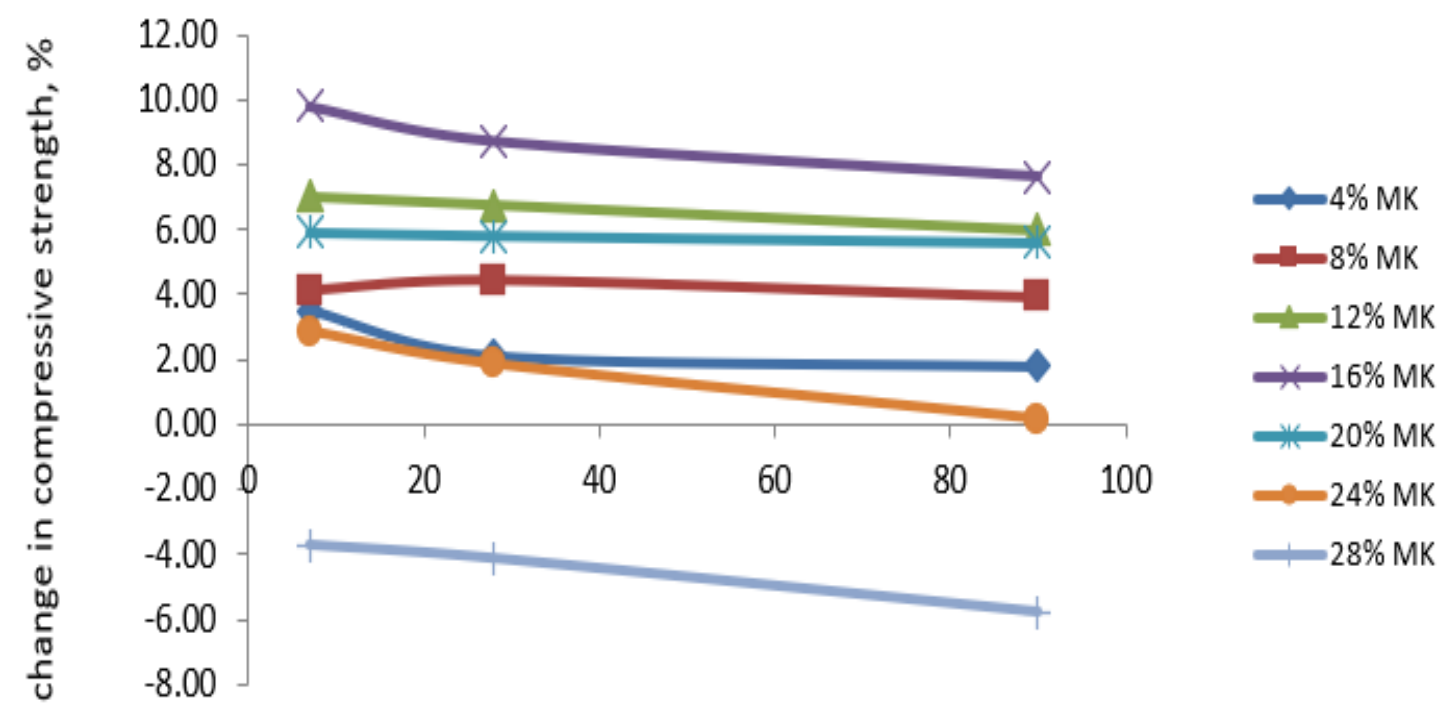

\section{Age of curing (Days)}

Figure 1. Variation of change in compressive strength of M40 concrete with MK percentages 


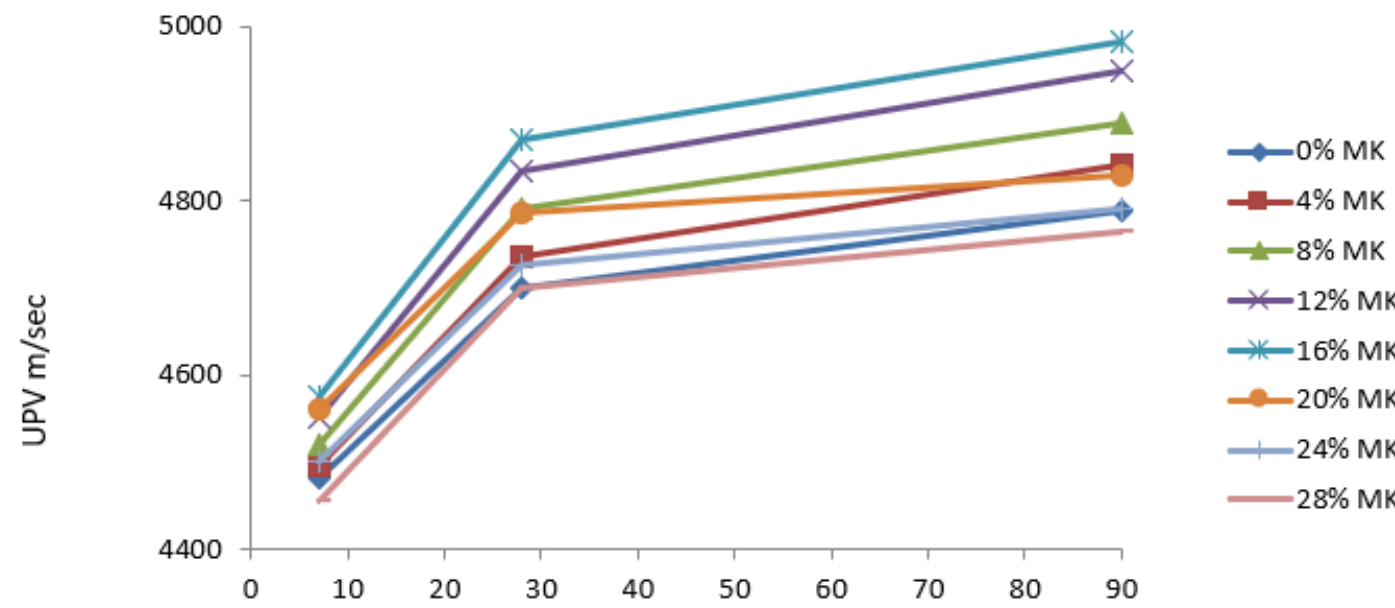

Age of Curing (Days)

Figure 2. Variation of ultrasonic pulse velocity of M40 concrete with different MK\%

It was found that gain in compressive strength for all mixes with $\mathrm{MK} \% 0$ to 24 . At $28 \% \mathrm{MK}$ replacement compressive strength was less than the control mix. Early age, 7 days strength gain is more as compare to 28 and 90 days strength. Percentage gain in 7 days compressive strength was $3.48 \%, 4.14 \%, 7.02 \%, 9.81 \%, 5.91 \%$ and $2.88 \%$ for $4 \%$ to $28 \% \mathrm{Mk}$ replacement respectively. After 90 days curing gain in strength was $1.8 \%, 3.93 \%, 5.98 \%, 7.6 \%$, $5.59 \%$ and $0.17 \%$ for $4 \%$ to $28 \%$ MK replacement respectively. The UPV test result of all specimens is shown in figure 2. The range of UPV values is between $4482 \mathrm{~m} / \mathrm{sec}$ to $4993 \mathrm{~m} / \mathrm{sec}$. It was observed that as MK \% increases UPV values also increases at all curing ages. Curing age also increased UPV value for all the mixes. Reduction in UPV values was observed after certain limit of MK replacement.

\subsection{Compressive Strength and Ultrasonic Pulse Velocity Relationship}

Taking into account the correlation between the compressive strength and UPV value of all concrete mixtures, the UPV and compressive strength of all concrete mixtures with a curing time of 7 to 90 days are plotted in Figure 3. The final relationship between the two is shown in Figure 3. The correlation coefficient $\left(\mathrm{R}^{2}\right)$ is 0.947 , indicating that $94.7 \%$ of the variation in compressive strength value has a linear relationship with the UPV shown in Figure 3.

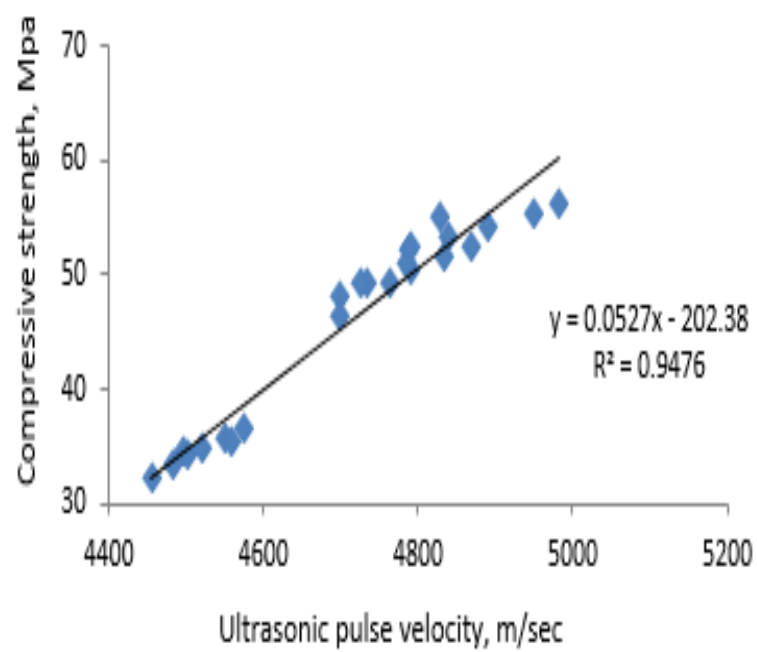

Figure 3. Relationship between cube compressive strength of M40 concrete and UPV

For the all results it had been found the subsequent model between compressive strength (fc in $\mathrm{MPa}$ ) and UPV $(\mathrm{V}$ in $\mathrm{m} / \mathrm{s})$ :

$$
\text { fc }=0.052 \mathrm{~V}-202.3
$$

Mathematical models for MK replacement percentage varying from $0 \%$ to $28 \%$ with the interval of $4 \%$ as shown in figure 4 gives the justification for the general equation (2) of M40 concrete. 


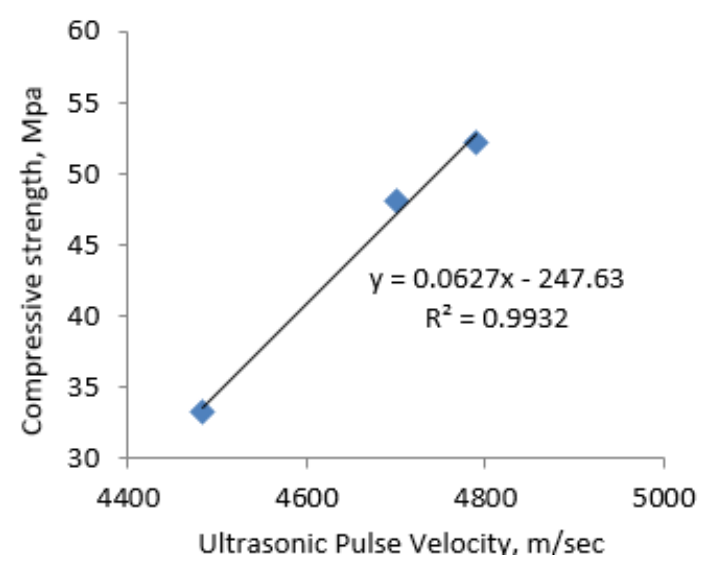

a) Normal concrete

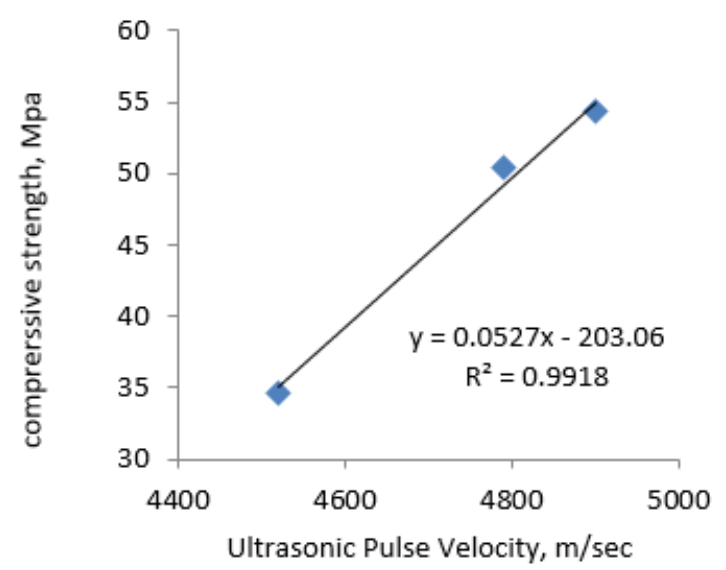

c) $8 \%$ MK concrete

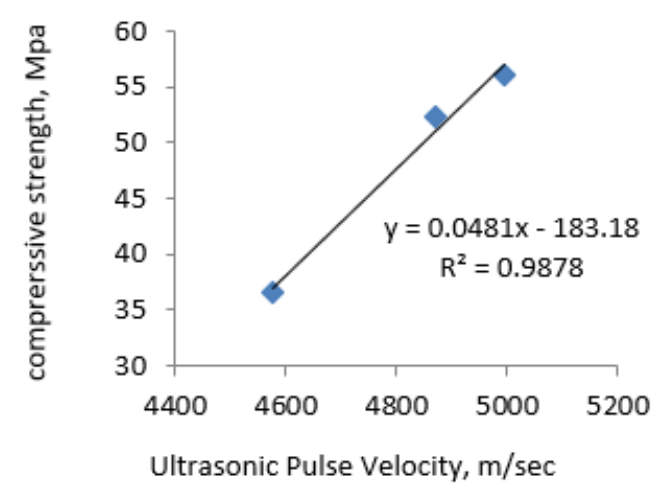

e) $16 \% \mathrm{Mk}$ concrete

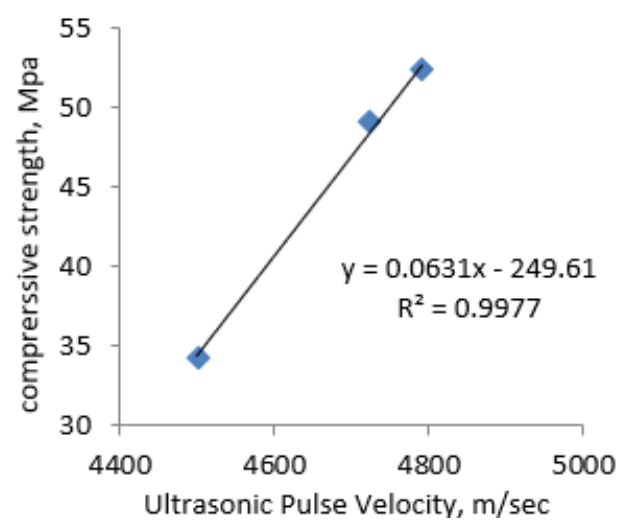

g) $24 \% \mathrm{MK}$ concrete

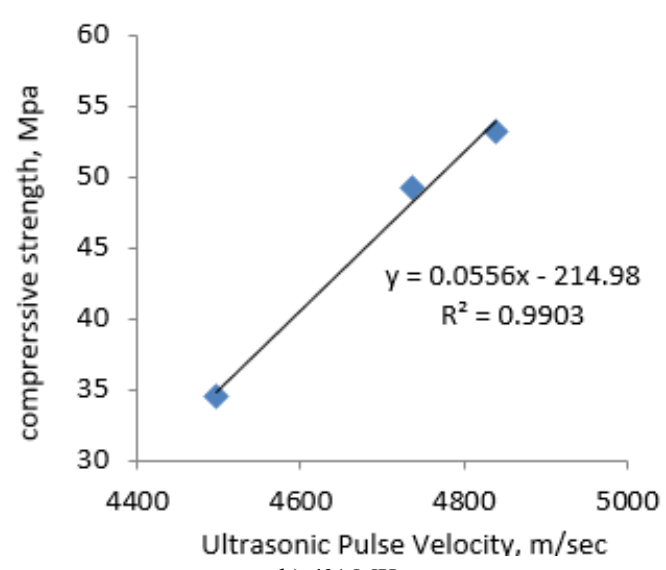

b) $4 \% \mathrm{MK}$ concrete

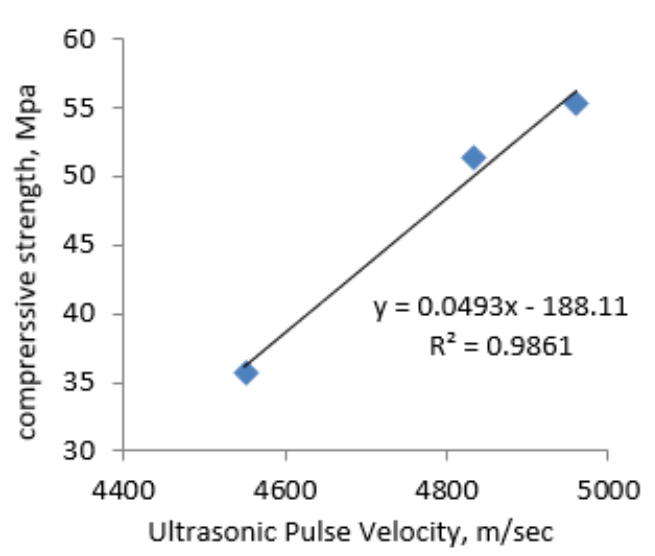

d) $12 \% \mathrm{MK}$ concrete

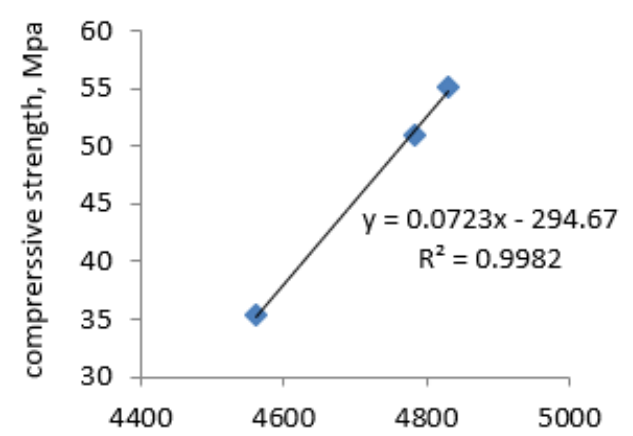

Ultrasonic Pulse Velocity, $\mathrm{m} / \mathrm{sec}$

f) $20 \%$ Mk concrete

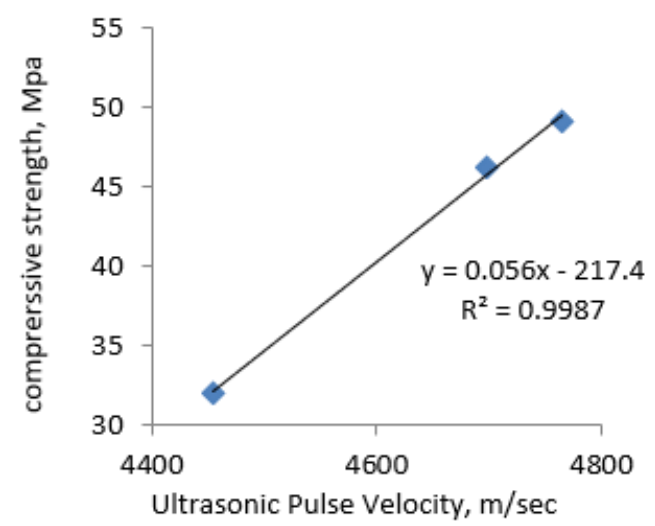

h) $28 \%$ MK concrete

Figure 4. (a-h) Relationship between concrete cube compressive strength and Ultrasonic Pulse Velocity for M 40 concrete. 
For individual model for MK replacement 4\%, 8\%, 12\%, $16 \%, 20 \%, 24 \%$ and $28 \%$ a linear relationship was also observed with the correlation coefficient $0.99,0.991,0.986$, $0.987,0.998,0.997$ and 0.998 respectively.

\section{Conclusions}

1. Addition of $\mathrm{MK}$ in the range of 4 to $24 \%$ had improved the compressive strength of normal concrete.

2. Early age compressive strength gain was more almost in all curing levels of MK concrete.

3. For all the MK mix Ultrasonic pulse velocity value was observed to be increase as the age of curing was increased.

4. Generalized equation between compressive strength range $35 \mathrm{MPa}$ to $55 \mathrm{MPa}$ and ultrasonic pulse velocity gives the good agreement between experimental and predicted values.

5. The model for different percentage of MK concrete can be used to calculate the compressive strength of concrete.

\section{REFERENCES}

[1] Justice, J.M., L.H. Kennison, B.J. Mohr, S.L. Beckwith and L.E. McCormick, Comparison of two metakaolins and a silica fume used as supplementary cementitious materials. Proceedings Seventh International Symposium on Utilization of High Strength/High Performance Concrete, June 20-24, 2005, Washington, DC., USA., pp: 1- 88.

[2] Poon, C.S.; Lam, L.; Kou, S.C.; Wong, Y.L.; Wong, R. Rate of pozzolanic reaction of metakaolin in high-performance cement pastes. Cement and Concrete Research, 2001,31 (9): 1301-1306.

[3] Wild, S.; Khatib, J. M.; Jones, A. Relative strength, pozzolanic activity and cement hydration in superplasticised metakaolin concrete. Cement and Concrete Research, 1996, 26(10), 1537-1544.

[4] Wild, S.; Khatib, J. M. Portlandite consumption of metakaolin cement Pastes and mortars. Cement and
Concrete Research, 1997, 27(1), 137-146.

[5] Emmanuel K.; Attiogbe ; Sami H. Rizkalla. Response of Concrete to Sulfuric Acid Attack, ACI Material Journal. Title no. 85-M46.

[6] K. Kawai, S. Yamaji, T. Shinmiet, Concrete Deterioration Caused by Sulfuric Acid Attack, 10 DBMC International Conférence On Durability of Building Materials and Components. 2005

[7] Dvorkin, L.; Bezusyak, A.; Lushnikova, N.; Ribakov, Y. Using mathematical modeling for design of self-compacting high strength concrete with metakaolin admixture. Construction and Building Materials, 2012, 37, 851-864.

[8] Wong HS; Razak HA. Efficiency of calcined kaolin and silica fume as cement replacement material for strength performance. Cement and Concrete Research 2005;35 (4):696-702.

[9] Popovics, S. Strength and Related Properties of Concrete - A Quantitative Approach. Nova York: John Wiley and Sons, 1998

[10] Sharmarke Abdi Omer; Ramazan Demirboga; Waleed H. Khushefati. Relationship between compressive strength and UPV of GGBFS based geopolymer mortars exposed to elevated temperatures. Construction and Building Materials 2015 (94) 189-195

[11] Tanigawa, Y.; Baba, K.; Mori, H., "Estimation of Concrete Strength by Combined Nondestructive Testing Method," In-Situ/Nondestructive Testing of Concrete, SP-82, V. M. Malhotra, ed., American Concrete Institute, Farmington Hills, Mich., 1984, pp. 57-76.

[12] Sturrup, V. R.; Vecchio, F. J.; Caratin, H., "Pulse Velocity as a Measure of Concrete Compressive Strength," In-Situ/Nondestructive Testing of Concrete, SP-82, V. M. Malhotra, ed., American Concrete Institute, Farmington Hills, Mich., 1984, pp. 201-227

[13] Lin, Y.; Changfan, H.; and Hsiao, C. Estimation of HighPerformance Concrete Strength by Pulse Velocity. Journal of the Chinese Institute of Engineers, V. 20, No. 6, 1998, 661-668.

[14] Lin, Y.; Lai, C. P.; and Yen, T. Prediction of Ultrasonic Pulse Velocity (UPV) in Concrete. ACI Materials Journal, V. 100, No. 1,. 2003, 21-28.

[15] Lin, Y.; Kuo, S-F; Hsiao C.; Lai, C-P. Investigation of Pulse Velocity- Strength Relationship of hardened Concrete. ACI Materials Journal, V. 104, No. 4, July.-Aug. 2007, 344- 350. 